\title{
INTRODUCTION
}

\section{Reorienting Ancient Judaism}

\section{Syrian, Mesopotamian, and Persian Perspectives*}

\author{
Jae Hee Han (Brown University) and \\ Annette Yoshiko Reed (New York University)
}

As much as has been written about ancient Israel as part of the ancient Near East, scholars have tended to turn westward when situating the nascence of Judaism. ${ }^{1}$ The Babylonian Exile in the sixth century B.C.E. is often hailed as a pivotal moment in this development: catalyzing the emergence of Jewishness as a portable identity, it marks the extrication of Israel's cult from ancient Israelite culture and the disembedding of Jewish identities from Judahite politics and place. ${ }^{2}$ If the Exile is thus lauded as a landmark in the prehistory of "Judaism" as "religion," however, it also marks the moment after which scholarship on ancient Jewish history and literature turns its focus away from the Near East. For the beginnings of Jewishness as an ethno-religious affiliation, scholars have looked to the advent of Hellenistic and Roman rule over the Land of Israel as determinative. ${ }^{3}$ Some studies have emphasized the interface

* This special issue of Journal of Ancient Judaism had its start in the $53^{\text {rd }}$ Philadelphia Seminar for Christian Origins (PSCO), which took up the theme of "Beyond 'Greco-Roman Context': Persian and Other Perspectives on Judaism and Christianity," with presentations by Simcha Gross, Yishai Kiel, Seth Sanders, and others. Our conceptualization here owes much to the year-long conversation at PSCO, for which we are especially grateful to co-chair James Shackelford and the other presenters: Aaron Butts, Matthew Canepa, Naomi KoltunFromm, Paul Kosmin, and John C. Reeves. Extending the insights and questions there, the present editors organized a follow-up panel focusing on Syro-Mesopotamia at the 2016 SBL Annual Meeting in the "Jewish-Christian/Christian Judaism" section, featuring presentations by Azzan Yadin-Israel, Karen Stern, and Zsuzsanna Gulácsi. We are grateful to Simcha Gross, Shaul Magid, Joshua Blachorsky, and Avi Moshe Miller for their comments and suggestions on this introduction.

1 On the convention of the distinction of pre-exilic "Israelites" from post-exilic "Jews," as well as the major shifts it marks, see e. g. S. Cohen, From the Maccabees to the Mishnah (Philadelphia: Westminster, 1987), 20-24; cf. already Josephus, Ant. 11.5.7.

2 Most influentially: S. Cohen, The Beginnings of Jewishness: Boundaries, Varieties, Uncertainties (Cambridge, MA: Harvard University Press, 1999).

3 It is perhaps telling, e.g., that the question of when and how Jewish identity came to bear a "religious" sense has centered almost wholly on the shifting meanings of Greek Ioudaios and Ioudaismos. See further, e. g., S. Mason, "Jews, Judaeans, Judaizing, Judaism: Problems of Categorization in Ancient History," JSJ 38 (2007): 457-512; C. Baker, Jew (Keywords in Jewish Studies; New Brunswick: Rutgers University Press, 2017); D. Boyarin, Judaism (Keywords in Jewish Studies; New Brunswick: Rutgers University Press, 2018). 
of "Hellenism" and "Judaism" in the Second Temple background to Christian Origins. ${ }^{4}$ Others have been concerned with mapping the range of Jewish reaction, response, and resistance to Roman and other Mediterranean cultures in counterpoint to modern Jewish experiences of the challenges of assimilation, acculturation, and Diaspora. ${ }^{5}$ Nevertheless, what remains common is the centering of "Greco-Roman context" in the historiography of ancient Jews and Judaism. ${ }^{6}$

In part, this tendency follows the patterns in our surviving evidence: the period of Achaemenid Persian rule over the Land of Israel still remains poorly attested in comparison with the eras following the conquests of Alexander the Great. ${ }^{7}$ Yet the focus on the "Greco-Roman context" also reflects a longstanding Eurocentrism, whereby the study of Ancient History has myopically privileged Greek and Latin materials, ${ }^{8}$ whereby Classical Studies has been the major disciplinary interlocutor for specialist research on ancient Judaism, ${ }^{9}$ and whereby ancient Judaism is assumed to have its ultimate telos in the mod-

4 Most influentially: M. Hengel, Judaism and Hellenism (2 vols.; Philadelphia: Fortress, 1974).

5 Questions of Jewish identity within and between North America and Israel, e.g., are presented as a key justification for the very study of Hellenistic Judaism, in particular, already in V. Tcherikover, Hellenistic Civilization and the Jews (trans. S. Applebaum; Philadelphia: Jewish Publication Society of America, 1959).

6 See discussion and references in A.Y. Reed and N. Dohrmann, "Rethinking Romanness, Provincializing Christendom," in Jews, Christians, and the Roman Empire: The Poetics of Power in Late Antiquity (eds. N. Dohrmann and A. Y. Reed; Jewish Culture and Contexts; Philadelphia: University of Pennsylvania Press, 2013), 1-22 - especially for a critique of the conventional usage of "Greco-Roman" in scholarship on ancient Judaism.

7 The lack of attention to the Achaemenid Persian empire and its continuities with later Hellenistic empires has been a longstanding issue within research in Classics, as noted already by A. Kuhrt and S. Sherwin-White (From Samarkhand to Sardis: A New Approach to the Seleucid Empire [Berkeley: University of California Press, 1993]; also Hellenism in the East: The Interaction of Greek and Non-Greek Civilizations from Syria to Central Asia after Alexandria [London: Duckworth, 1987]). See also, more recently, R. Strootman, Courts and Elites in the Hellenistic Empires: The Near East after the Achaemenids, c. 330 to 30 BCE (Edinburgh: Edinburgh University Press, 2014).

8 For this point see F. Millar, "Redrawing the Map," in Rome, the Greek World, and the East (eds. H. M. Cotton and G. M. Rogers; Chapel Hill: UNC Press, 2006), 3:487-509 - there noting how "There could be a perfectly valid [alternate] framework (and educational syllabus) of 'ancient history' which took as its central focus the Levant or the eastern Mediterranean of (say) the first millennium $\mathrm{BC}$ and the first millennium $\mathrm{AD}$, up to the Islamic conquests, and from that perspective would incorporate the emergence of Greek literature, the rise of the Greek city-state, and the spread of Greek colonisation on the one hand, and late Pharaonic Egypt on the other, as well as Phoenicia, the Aramean kingdoms, Israel and Judah, and the Neo-Assyrian, Babylonian, and Persian empires" (506).

9 Hence, e. g., even despite the widely-noted resurgence of Near Eastern traditions in Hellenistic- and Roman-era Jewish apocalypses, they have been only rarely studied in relation to the Near East - a pattern noted already in the 1970s by John Collins (e.g., "Jewish Apocalyptic against its Hellenistic Near Eastern Environment," BASOR 220 [1975]: 27-36) but not concertedly picked up again until quite recently (on which see discussion in A. Y. Reed, "Writing Jewish Astronomy in the Early Hellenistic Age: The Enochic Astronomical Book as Aramaic Wisdom and Archival Impulse," DSD 24 [2017]: 1-37). 
ern West. ${ }^{10}$ To the degree that wider questions about Jewishness have been explored through the lens of antiquity, it has been with an eye to "accommodation" and "resistance" to Hellenistic and Roman cultures." To the degree that specialists in ancient Judaism have theorized "influence," it has been primarily with reference to non-Jewish literature in Greek and Latin. ${ }^{12}$ Likewise, to the degree that studies of ancient Judaism have attended to empire, it has been foremost with Rome in mind - not least because of the traditional tendency to focus on Jewish military revolts against Roman rule and to treat the Roman destruction of the Jerusalem Temple in 70 C.E. as a "watershed moment" in Jewish history. ${ }^{13}$ Accordingly, in traditional research as today, the drama of the development of ancient Judaism has been staged against the backdrop of "the Greco-Roman world."14

But what perspectives and insights might we gain when we look beyond the "Greco-Roman context" when situating ancient Jews and Judaism, even after the conquests of Alexander the Great? And how might attention to Syrian, Mesopotamian, and Persian local and imperial contexts, in particular, offer alternate perspectives on the cultural dynamics typically discussed as Jewish

10 Reflecting on this telos in the historiography of Christianity, e. g., Peter Brown reminds us of Europe's status in Late Antiquity as "only the westernmost variant of a far wider Christian world, whose center of gravity lay, rather in the eastern Mediterranean and in the Middle East"; The Rise of Western Christendom: Triumph and Diversity, A.D. 200-1000 ( $2^{\text {nd }}$ ed.; Oxford: Oxford University Press, 2003), 2. See further A. Y. Reed, "Beyond the Land of Nod: Syriac Images of Asia and the Historiography of the 'West," History of Religions 49.1 (2009): 48-87.

11 For an explicit example of the importation of terminology of "assimilation," etc., from discussion of American Jewry to discuss ancient Judaism see John Barclay, Jews in the Mediterranean Diaspora (Berkeley: University of California Press, 1999). More recently, as Simcha Gross notes in his article below, rubrics of "accommodation" and "resistance" have also been imported from the study of American Jewry into the study of Babylonian Jews in Late Antiquity.

12 I.e., both "pagan" and Christian. On the problems with "influence" as an analytical tool, for instance, see P. Schäfer, "Introduction," in The Talmud Yerushalmi and Graeco-Roman Culture I (ed. P. Schäfer; Tübingen: Mohr Siebeck, 1998), 14-15 - as well as discussion below by Azzan Yadin-Israel.

13 I. e., marking the end of the Second Temple period and the beginning of the era of the rise of the Rabbis. See further Reed and Dohrmann, "Rethinking Romanness"; D. R. Schwartz and Z. Weiss, eds., Was 70 C. E. a Watershed in Jewish History? On Jews and Judaism before and after the Destruction of the Second Temple (Leiden: Brill, 2011); cf. S. Schwartz, Imperialism and Jewish Society, 200 B.C.E. to 640 C.E. (Princeton: Princeton University Press, 2002), 103-10; idem, "Was There a 'Common Judaism' after the Destruction?" in Envisioning Judaism: Studies in Honor of Peter Schäfer on the Occasion His $70^{\text {th }}$ Birthday (eds. R. Boustan et al.; Tübingen: Mohr Siebeck, 2013), 1.3-22.

14 See above on the Second Temple period, and in the case of the Rabbinic movement see P. Schäfer, ed., The Talmud Yerushalmi and Graeco-Roman Culture I (TSAJ 71; Tübingen: Mohr Siebeck, 1998); P. Schäfer and C. Heszer, eds., The Talmud Yerushalmi and GraecoRoman Culture II (TSAJ 79; Tübingen: Mohr Siebeck, 2000); P. Schäfer, ed., The Talmud Yerushalmi and Graeco-Roman Culture III (TSAJ 93; Tübingen: Mohr Siebeck, 2002); S. Schwartz and R. Kalmin, eds., Jewish Culture and Society under the Christian Empire (Leuven: Peeters, 2002); H. Lapin, Rabbis and Romans: The Rabbinic Movement in Its LateAntique Provincial Setting (Oxford: Oxford University Press, 2012). 
"borrowing," "influence," "assimilation," and "resistance" in relation to both "pagan" and Christian cultures? These are the questions that we seek experimentally to explore in this special issue of the Journal of Ancient Judaism, by bringing three recent scholarly trends into conversation.

Most prominent among these trends is the renewed attention to the Sasanian Persian Empire among specialists of the Babylonian Talmud, inspired by the groundbreaking work of Yaakov Elman. ${ }^{15}$ Recent years have seen the emergence of Irano-Talmudica as a subfield in its own right, pollinated by fresh interest in parallels between Rabbinic Judaism and Syriac Christianity. ${ }^{16}$ Reflections and retrospectives on this trend already abound. ${ }^{17}$ Here, however, we seek to engage some of its fruits in relation to research on two earlier periods in which "the Greco-Roman world" coexisted in culturally productive ways with Syrian, Mesopotamian, and Persian local and imperial contexts. ${ }^{18}$

On the one hand, the discovery of the Dead Sea Scrolls sparked a new recognition of the degree to which Mesopotamian scholasticism continued to impact Jewish knowledge-making into the Hellenistic period and well beyond. ${ }^{19}$ On the other hand, recent interdisciplinary research on Late Antiq-

15 For the historiography of the Talmud's Sassanian settings see Simcha Gross' article below.

16 Recent examples include C. Bakhos and M. R. Shayegan, eds., The Talmud in Its Iranian Context (TSAJ 135; Tübingen: Mohr Siebeck, 2010); S. Secunda, The Iranian Talmud: Reading the Bavli in its Sasanian Context (Philadelphia: University of Pennsylvania Press, 2014); U. Gabbay and S. Secunda, eds., Encounters by the Rivers of Babylon: Scholarly Conversations between Jews, Iranians, and Babylonians (TSAJ 160; Tübingen: Mohr Siebeck, 2014); J. Mokhtarian, Rabbis, Sorcerers, Kings, and Priests: The Culture of the Talmud in Ancient Iran (Berkeley: University of California Press, 2015); Y. Kiel, Sexuality in the Babylonian Talmud: Christian and Sasanian Contexts in Late Antiquity (Cambridge: Cambridge University Press, 2016); G. Herman and J.L. Rubenstein, eds., The Aggada of the Bavli and its Cultural World (Brown Judaic Studies series; Providence: SBL, 2018). On the adducing of Syriac parallels see also discussion and references in G. Herman and J. L. Rubenstein, "Introduction, in The Aggada of the Bavli and its Cultural World, xiii-xxvi; A.H. Becker, "The Comparative Study of 'Scholasticism' in Late Antique Mesopotamia: Rabbis and East Syrians," AJS Review 34 (2010): 91-113; idem, "Polishing the Mirror: Some Thoughts on Syriac Sources and Early Judaism," in Envisioning Judaism, 2:897-915.

17 Note especially the $2016 J Q R$ forum, including R. Brody, "Irano-Talmudica: The New Parallelomania?” JQR 106 (2016): 209-32; S. Secunda, “'This' but Also 'That': Historical, Methodological, and Theoretical Reflections on Irano-Talmudica," JQR 106 (2016): 233-41; S. Gross, "Irano-Talmudica and Beyond: Next Steps in the Contextualization of the Babylonian Talmud," JQR 106 (2016): 248-55.

18 For this reason we do not include discussion of the Achaemenid Persian period. For recent trends in research in that period, see e.g. L. Grabbe, A History of the Jews and Judaism in the Second Temple Period, vol. 1: The Persian Period (539-331 B. C. E.) (London: T\&T Clark, 2006); O. Lipschitz and M. Oeming, eds., Judah and the Judeans in the Persian Period (Winona Lake: Eisenbrauns, 2006); J.L. Berquist, ed., Approaching Yehud: New Approaches to the Study of the Persian Period (Atlanta: SBL, 2007).

19 Reed, "Writing Jewish Astronomy"; J. Ben-Dov, Head of All Years: Astronomy and Calendars at Qumran in their Ancient Context (Leiden: Brill, 2008); H. Drawnel, The Aramaic Astronomical Book (4Q208-4Q211) from Qumran (Oxford: Oxford University Press, 2011); J. Ben-Dov and S. L. Sanders, eds., Ancient Jewish Sciences and the History of Knowledge in 
uity has inspired fresh interest in the Syro-Mesopotamian domains on the shifting borders of the Roman Near East onto Parthian and Sasanian empires, as a "contact zone" and crucible of cultural creativity for Jews no less than Platonists, Christians, and Manichaeans in the first three centuries of the Common Era. ${ }^{20}$ Attention to these earlier moments might help us to put the Babylonian Talmud's engagement with Sasanian culture into broader historical and historiographical perspectives. By bringing together articles that speak to these different eras, moreover, it is our hope to counterbalance the longstanding tendency to focus on the "Greco-Roman context" of ancient and late antique Judaism, opening up new vistas and questions.

Even under the impact of Greek language and learning, the region of SyroMesopotamia and the shifting empires of Persia continued to have a persistent place both in the Jewish literary imagination and in the making of Jewish identities, long after the conquests of Alexander and the rise of the empires of his successors. If anything, in fact, the era that saw the initial spread of Greek paideia and translocal "Greekness" was a period in which Jewish scribes turned their gaze eastward with fresh inventiveness and poignant nostalgia. Second Temple texts like Esther and Daniel tell of Jews in Persian and other Near Eastern imperial courts. Texts like the Enochic Astronomical Book, Book of the Watchers, and Book of the Giants went even further, repurposing the Persian administrative language of Aramaic into a Jewish literary language, while also laying claim to Mesopotamian myth and scholasticism as the antediluvian heritage of Judaean scribes. ${ }^{21}$ The probability of a continued Jewish presence in Babylon throughout the Second Temple period makes such connections all the more intriguing. ${ }^{22}$

Likewise, the many changes to Jewish life with the ascendancy of Roman power are perhaps not wholly legible without situating Roman Palestine as part of the Roman Near East and attending to the Parthian and Sasanian em-

Second Temple Literature (New York: NYU Press, 2014); S. L. Sanders, From Adapa to Enoch (TSAJ 167; Tübingen: Mohr Siebeck, 2017).

20 See the articles below by Azzan Yadin-Israel, Karen Stern, and Zsuzsanna Gulácsi, as well as F.S. Jones, Pseudoclementina Elchasaiticaque inter Judaeochristiana: Collected Studies (Leuven: Peeters, 2012); N. J. Andrade, Syrian Identity in the Greco-Roman World (Cambridge: Cambridge University Press, 2013); A. Y. Reed, "Beyond 'Judaism' and 'Christianity' in the Roman Near East," in Jewish-Christianity and the History of Judaism (TSAJ 181; Tübingen: Mohr Siebeck, 2018), 57-84; J.H. Han, "Rethinking Prophecy in Late Antique Syria" (Ph. D. diss., University of Pennsylvania, 2018). For reflections on connections with the above-noted trends in the study of the Talmud, see also R. Kalmin, "The Bavli, the Roman East and Mesopotamian Christianity," JQR 106 (2016): 242-47.

21 See Seth Sander's article below as well as Sanders, From Adapa; A. Lenzi, Secrecy and the Gods: Secret Knowledge in Ancient Mesopotamia and Biblical Israel (Helsinki: Neo-Assyrian Text Corpus Project, 2008), 307-75.

22 On the continued presence of Judeans in Mesopotamia, see now R. Zadok, "Judeans in Babylonia: Updating the Dossier," in Encounters by the Rivers of Babylon, 109-29. 
pires too. ${ }^{23}$ In the Roman and Byzantine empires, Late Antiquity was marked by the emergence of the multiple forms of Jesus-oriented Jewish messianism that came to be known as "Christianity" but also the emergence of the Rabbinic movement, monumental synagogues, and piyyutim. ${ }^{24}$ In the same period, to the east, the Babylonian Talmud and Jewish Babylonian Aramaic incantation bowls bear witness to new forms of Jewish literary and material production. ${ }^{25}$ The prehistory of the Hekhalot literature and Toledot Yeshu seem to owe much to both sets of imperial and local cultures. ${ }^{26}$ Here too, still or again, the relationship between Mesopotamia and the Land of Israel proves richer and more complex than can be conveyed by any simple contrast of landedness and exile. ${ }^{27}$

Taken together, these recent trends demonstrate the limits of the common treatment of the "Greco-Roman world" as uniquely incubating ancient Jewishness or as the prehistory of "Judaism" as "religion." ${ }^{8}$ Whether or not the perspective of late antique Christian heresiologists can be generalized to Jews

23 M. Canepa, The Two Eyes of the Earth: Art and Ritual of Kingship between Rome and Sasanian Iran (Berkeley: University of California Press, 2009). For more on the Church of the East within the Sasanian milieu, see R.E. Payne, A State of Mixture: Christians, Zoroastrians, and Iranian Political Culture in Late Antiquity (Berkeley: University of California Press, 2015).

24 On synagogues and material culture in Syria and Mesopotamia, in particular, see references and discussion below by Karen Stern and Zsuzsanna Gulácsi.

25 On magic bowls see references and discussion in Yishai Kiel's article below as well as Y. Elman, "Saffron, Spices, and Sorceresses: Magic Bowls and the Bavli," in Daughters of Hecate: Women and Magic in the Ancient World (eds. K. B. Stratton and D. Kalleres; Oxford: Oxford University Press, 2014), 365-85.

26 P. Schäfer, M. Meerson, and Y. Deutsch, eds., Toledot Yeshu ("The Life Story of Jesus") Revisited (TSAJ 143; Tübingen: Mohr Siebeck, 2011); R. Boustan, M. Himmelfarb and P. Schäfer, eds., Hekhalot Literature in Context: Between Byzantium and Babylonia (TSAJ 153; Tübingen: Mohr Siebeck, 2013).

27 Babylonian sages, e. g., sometimes claim to preserve a purer lineage than their counterparts who lived in Roman Palestine and to argue for Babylonian Jews as superior purveyors of Torah (b. Qidd. 71a-72b); see further J.L. Rubenstein, The Culture of the Babylonian Talmud (Baltimore: John Hopkins University Press, 2003), 84-99; Isaiah Gafni, "Expressions and Types of 'Local Patriotism' among the Jews of Babylonia," in Irano-Judaica II (eds. Shaul Shaked and A. Netzer; Jerusalem: Yad Izhaq Ben-Zvi, 1990), 63-73; A. Oppenheimer, Babylonia Judaica in the Talmudic Period (Göttingen: Wiesbaden, 1983), 16-17. Perhaps responding to Zoroastrian claims regarding the sanctity of Iran-shahr, moreover, some sages debated the regions of pure Jewish lineage even within the Sasanian Empire, echoing discourses and practices that Syriac Christians would deploy to reconfigure Iran as a Christian land (Payne, A State of Mixture, 59-92).

28 D. Boyarin, Border Lines: The Partition of Judaeo-Christianity (Philadelphia: University of Pennsylvania Press, 2006); idem, "Rethinking Jewish Christianity: An Argument for Dismantling a Dubious Category (to which is Appended a Correction of my Border Lines)," JQR 99 (2009): 7-36; S. Schwartz, "How Many Judaisms Were There? A Critique of Neusner and Smith on Definition and Mason and Boyarin on Categorization," JAJ 2 (2011): 208-38; cf. A. H. Becker, "Martyrdom, Religious Difference, and 'Fear' Category of Piety in the Sasanian Empire: The Case of the Martyrdom of Gregory and the Martyrdom of Yazdpaneh," JLA 2 (2009): 300-36; A. Y. Reed, “After 'Origins,' Beyond 'Identity,' and Before 'Religion(s),'” in Jewish-Christianity, 389-438. 
in the Roman empire, for instance, it remains that Sasanian contexts caution against globalizing such sources into any monolithic narrative about "Judaism" and "Christianity" writ large. In a classic essay, "Beyond the Spatial and Temporal Limes," Adam H. Becker asked about the extent to which scholarly meta-narratives based on the relationships between Jews and Christians in the Roman Empire also make sense in the Sasanian Empire. ${ }^{29}$ To this, we might add that taxonomies of ritual practice and collective identity are mapped quite differently as well. In the middle of his Res Gestae in Naqsh-i-Rustam, for instance, the Zoroastrian priest Kartir casts "Jews, Buddhists, Brahmins, Nazoreans, Christians, Baptizers, and Manichaeans" from a single cloth as those who inculcate and practice the teachings of Ahriman and his demons. ${ }^{30}$ This classification of difference thus stands in striking contrast both to contemporaneous Christian heresiological discourses, which marshal "the Jews" for a Christian imperial project, and to rabbinic Jewish categorizations of difference through rubrics like minut, kutim, 'am ha'aretz, and goyim. ${ }^{31}$ The coexistence of these various positionalities and perspectives, in turn, points to the value of situating ancient Jewish texts and material cultures in multiple nested and overlapping contexts and simultaneous trajectories.

To be sure, scholars have learned much about identity and self-definition by situating ancient Jewish materials in their "Greco-Roman contexts." As elsewhere, however, the choice of "context" is a matter of selectivity, which reflects longstanding habits of representation and which forecloses some vistas even as it opens others. At the level of modern scholarly practice, this particular framing serves to set a broad spatial and temporal horizon for our acts of contrast and comparison (i.e., spanning the eastern Mediterranean and Near East from Alexander to the rise of Islam). Yet it simultaneously naturalizes a very narrow range of Greek and Latin texts as the main reservoir of sources to serve as comparanda when situating ancient Jews and Judaism. To turn our focus eastwards - to Syrian, Mesopotamian, and Persian contexts - is not just to re-center and enlarge the geographical horizons of our vistas onto the Jewish past; it is also to expand the languages and corpora of our comparanda

29 A.H. Becker, "Beyond the Spatial and Temporal Limes: Questioning the 'Parting of the Ways' Outside the Roman Empire," in The Ways That Never Parted: Jews and Christians in Late Antiquity and the Early Middle Ages (eds. A. H. Becker and A. Y. Reed; TSAJ 75; Tübingen: Mohr Siebeck, 2003), 373-92.

30 T. Daryaee, Sasanian Persia: Rise and Fall of an Empire (London: I. B. Tauris, 2009), 75-81.

31 For recent discussions of such classificatory rubrics and practices see T. Berzon, Classifying Christians: Ethnography, Heresiology, and the Limits of Knowledge in Late Antiquity (Berkeley: University of California Press, 2016); D. M. Grossberg, Heresy and the Formation of the Rabbinic Community (TSAJ 128; Tübingen: Mohr Siebeck, 2017); C. Hayes, "The Complicated Goy in Classical Rabbinic Sources," in Perceiving the Other in Ancient Judaism and Christianity (eds. M. Bar Asher Siegal and M. Thiessen; Tübingen: Mohr Siebeck, 2017), 147-67; A. Ophir and I. Rosen-Zvi, Goy: Israel's Others and the Birth of the Gentile (Oxford: Oxford University Press, 2018); M. Chalmers, "The Samaritan Other: Representations of Samaritans in Late Antique Jewish and Christian Texts" (Ph. D. diss., University of Pennsylvania, in progress). 
so as to include also the cuneiform sources by which Mesopotamian scholasticism was transmitted well into the Seleucid period, the Syriac writings of Christians and Manichaeans outside of the Roman Empire, and Middle Iranian and other sources for Zoroastrianism and Sasanian culture as well. ${ }^{32}$ In the process, we may be able to glimpse dynamics of ancient Jewish selfdefinition that differ from the well-known patterns established through comparison with Greek and Latin sources.

Such a shift in orientation, then, also pushes us to reflect upon our own scholarly habits of contextualization and what we thereby treat as representative. When making points about the "Christianity" that ancient Jews ignored, resisted, or reacted against, for instance, scholars have been in the habit of selectively quoting from a small set of Church Fathers who wrote in Greek and Latin, such as Ignatius, Justin, Origen, and Augustine. To turn our attention eastward, however, is also to wonder whether what some late antique Jews encountered as "Christianity" might have differed, depending on their locale. In Mesopotamia, what was encountered as "Christian" in the second century might have been more like the Book of Elchasai, and in the third and fourth centuries, perhaps more like Bardaisan, Ephrem, Aphrahat, or the Pseudo-Clementines. Or maybe such encounters did not involve texts at all but rather primarily images, such as those in the church at Dura-Europos or in Manichaean Book of Pictures.

What did Jewishness look like to and among Platonists in Syria, Manichaeans in Mesopotamia, and Zoroastrians in Sasanian Persia? How did it differ from what scholars have reconstructed as "ancient Judaism" on the basis of centering its expressions and interlocutors? How might this evidence challenge or relativize models of Jewish identity common in the Roman Empire and the modern West - which tend to constellate around binaries like Jew/ goy, "Judaism"/"Hellenism," and "Judaism"/"Christianity"? How might attention to multiple local and imperial contexts enable tracing alternative or simultaneous histories or trajectories - not from a single presumed center to its purported peripheries, but rather across constellations of multiple centers?

The present volume does not claim to answer all of these questions, but it does aim to model the type of reorientation that enables productive conversation about them across different periods and corpora of ancient Judaism. In the opening article, Seth Sanders points to the conventional scholarly equation of Enoch and Enmeduranki as a parade example of the problems that arise when the study of ancient Judaism neglects engagement with specialist research on Mesopotamia. Even though this equation was made nearly one hundred years ago and does not fit cuneiform evidence published since then, it remains repeated to this day by scholars of Second Temple Judaism. In the

32 On the methodological issues surrounding the choice of comparanda see the article by Seth Sanders below, and on the modern scholarly practice of comparison see also the articles by Azzan Yadin-Israel and Simcha Gross. 
course of tracing the origins and diffusion of this equation, Sanders highlights methodological shortcomings in the treatment of cultural connections and selectivity of comparanda in the study of Judaism more broadly. The literary production of the late Second Temple period, as Sanders notes, is marked by a "new intensity with which patterns found in neighboring cultures manifest themselves," which includes but is not limited to Hellenism. Past research, however, has been marked by decontextualized parallels and unidirectional theories of "influence" that do not do justice to the complex web of interconnected Greek and Near Eastern traditions within the oikoumene of the time. To look anew to the relevant evidence from Mesopotamia is necessary for understanding how traditions about Enoch fit within this web. Such analysis reveals Adapa, rather than Enmeduranki, as the more relevant Babylonian comparison, and it also enables a more nuanced characterization of Judaean and Babylonian scribal cultures, in their commonalities as well as their differences.

The next two articles turn to examine our theme through the lens of the material culture of late antique Syro-Mesopotamia, focusing on the synagogue at Dura-Europos. Karen Stern highlights Dura's status as "an exquisitely rare snapshot of a town, sequentially overrun and transformed by different empires... posed geographically, culturally, and politically between the Hellenistic, Parthian, Roman, and Sasanian worlds."

To illumine this overlap, she breaks from studies that situate the synagogue within the study of monumental architecture, turning instead to consider the vestiges of the structure's use - such as graffiti, dipinti, and burial of objects which point to how visitors moved through its spaces. She considers the graffiti inscriptions in the Durene synagogue in light of similar inscriptions found both within Dura and across Syria, Mesopotamia, and Persia. Drawing out dynamics of writing, spatiality, and sanctity, Stern argues for understanding the "activities of Dura's inhabitants... as distinctively and simultaneously Syrian, Mesopotamian, and Persian."

Just as Stern stresses the potential of Dura for testing "tentative hypotheses about the emergences of multiple and overlapping religious communities" in this region, so Zsuzsanna Gulácsi experiments with a fresh approach to the murals in the Durene synagogue by considering them in light of an example of the use of images by the leader of a religious community emerging in Mesopotamia right around the same time that narrative panels were added to the synagogue during its renovation in 244/245 C. E. - that is, Mani (fl. 240-274/277 C.E.). Gulácsi surveys the evidence for Mani's Book of Pictures, which has been largely ignored in the traditionally Latin-based study of Manichaeism, and she deploys its concerns and functions as neglected comparanda for the much-discussed art of the Durene synagogue. By refracting the lavish paintings encircling the interior of the synagogue through what can be known of Mani's Book of Pictures, she highlights shared concerns of prophetology, eschatology, and polemics, while also using the comparison to posit a didactic 
function for Durene art as well. The parallels between them - Gulácsi suggests - enables us to situate Dura in a manner "not limited to the city, nor even stopping at the often-changing and culturally porous border of the Roman Empire" but rather oriented eastwards.

Azzan Yadin-Israel similarly takes up questions of cultural contact with a focus on literary sources from Coele-Syria. At the heart of his paper is a methodological reflection on continuity and comparison. Yadin-Israel focuses on the critiques of animal sacrifice by Palestinian rabbis, noting how scholars have tended to take for granted their continuity with biblical precedents as exhausting the need for explanation and thus not looked to their context or non-Jewish comparanda. Yet, Yadin-Israel notes, it remains intriguing that critiques of animal sacrifice are similarly voiced around the same time by the Syrian Platonists Iamblichus and Porphyry as well as by Syrian Christian sources like the Didascalia apostolorum and Pseudo-Clementines. In part, the lack of attention to these parallels reflects the habitual neglect of the Syrian identities of these Greek-writing Platonists: "perhaps modern scholars would be more amenable to the idea of cultural exchange between rabbis and late antique Platonists," as Yadin-Israel notes, "if we spoke of the Syriacspeaking Bible scholar Malkus, Porphyry's given name, and his opponent, Yamliku, the Aramaic name of Iamblichus." Yadin-Israel, however, focuses on the methodological problems with the conventional modern scholarly practice of treating inner-Jewish continuity as a given while only allowing for the explanatory relevance of non-Jewish traditions in clear cases of direct literary dependence. To map out theoretical alternatives that make more sense of our evidence, Yadin-Israel looks to contemporary linguistic theories concerning grammatical calquing and areal diffusion. These may offer a more helpful model, he suggests, for understanding why "the theological critique of sacrifice was shared by a significant number of communities in Coele-Syria," in a manner akin to a common grammar, even as rabbis, philosophers, and Christians also each used this grammar to voice distinctive critiques in their own terms.

With the articles of Yishai Kiel and Simcha Gross, we shift to Jews in the Sasanian Empire. Kiel uses one Babylonian incantation bowl, M 163, to illumine the "numerous overlaps and intersections between the talmudic, magical, and mystical corpora" that speak to the cultural dynamism of Babylonian Jews in interaction with Christian, Mesopotamian, and Iranian traditions within their Sasanian milieu. Such interaction, as he shows, encompasses the expression of a common magic culture shared by Jews and others. Yet it also goes beyond it. Kiel thus analyzes key terms and figures in the text of this bowl (e.g., white rooster, Jesus, Metatron, HRWM AHRWM) with reference to a broad range of literary corpora, including the Babylonian Talmud, 3 Enoch, and Sefer Zerubavel as well as Zoroastrian traditions. In the process, he uses this example to counter the longstanding "myth of autonomous religious communities that coexisted in isolation in the Sasanian Empire," while also 
emphasizing how Jews “were not 'influenced' by the surrounding Sasanian culture so much as they were an integral part of it."

In the final article of this journal, Simcha Gross focuses on a narrative about Rav Nahman and Rav Yehuda in b. Qiddushin 70a-b to argue for the importance of attending to the specificity of the Sasanian context when contextualizing the Babylonian Talmud. Past scholars have often read this narrative as an argument about Jewish use of the Persian language, adducing it as evidence for a Jewish debate about "accommodation" and "resistance" to Sasanian culture. Gross proposes that one can better read these passages as evidence of differing inner-rabbinic strategies for negotiating status within the Jewish community - albeit both participating within their Sasanian context. Gross scaffolds his reading of this passage with reference to overlooked sources about Sasanian culture and society preserved in Middle Persian. When read in this context, the debate is revealed to revolve around the issue of elitism and social capital, both in relation to the contestation of language usage and in relation to banqueting practices and treatment of women; as Gross shows, "there is no evidence that the use of the Persian language was viewed as problematic by the Babylonian rabbis." What is at stake, rather, is the question of the basis on which to advance one's social status within the Babylonian Jewish community, and the battle is between "Torah capital," based on rabbinic language and norms, and social capital, based on Sasanian elite habitus. Through this example, thus, Gross draws out competing elite strategies in the Sasanian Empire, some of which find parallels in Syriac Christian sources as well. At the same time, he models an approach to using Middle Persian sources for reading Talmudic sources that goes beyond simplistic models of "influence," showing instead how even internal rabbinic debates could be couched within Sasanian cultural idioms.

By reorienting the lens of our inquiries to center eastern locales, our aim here is not to reverse the polarities of Orientalist discourse by positing essential differences between the Greco-Roman "West" and the Syro-Mesopotamian and Persian "East." Rather, by bringing specialist discussions into conversation with one another around issues of locality, identity, and empire, we hope to experiment with alternative models of comparative analysis, ask methodological questions regarding what counts as relevant comparanda, and deliberate the value of understudied materials (e.g., synagogal graffiti; magic bowls) and unculled comparanda (e.g., Syrian Platonism; Zoroastrian sources; Manichaean iconography) for the study of ancient and late antique Jewish literature and history. In the process, we hope to open the way for fresh approaches to ancient and late antique Judaism that reclaim Syria, Mesopotamia, and Persian perspectives from their relegation to the periphery of modern scholarly research. 